\title{
Transformaties van de Argonautenmythe in de roman Een vreemde stam heeft mij geroofd van Willem Brakman
}

\begin{abstract}
The following article deals with the transformation of the myth of Jason and the Argonauts in the novel Een vreemde stam heeft mij geroofd (1992) written by Willem Brakman. The legend of the Argonauts tells about a mythical journey in quest of the Golden Fleece. Working on his own version, Brakman relied on the epic poem The Argonautica written in the 3rd century BC by Apollonius of Rhodes. Brakman rewrote the myth of the Argonauts by placing the action in 20th-century Netherlands. The research aim is to discover in what way Brakman transforms the original story as set in The Argonautica and to compare these two versions. Brakman's novel differs from the original in the changes to the plot or characters. Moreover, he combines the legend of the Argonauts with other mythical stories such as that of Oedipus, Odysseus, Theseus. Gérard Genette's theory of intertextuality serves as the theoretical background of the article.
\end{abstract}

Keywords: the Argonauts, the Golden Fleece, theory of intertextuality, parody, transposition.

\section{Inleiding}

Het doel van deze bijdrage is de roman Een vreemde stam heeft mij geroofd van Willem Brakman te vergelijken met De Argonautica van Apollonius Rhodius. Uit de vergelijking zal blijken in welke mate Brakman zich aan Apollonius' versie heeft gehouden en welke wijzigingen hij aangebracht heeft. Daarbij zullen we gebruik maken van de intertekstualiteitstheorie van Gérard Genette om te laten zien welke procedés ter beschikking staan aan een schrijver die de oorspronkelijke bron omzet. In het voorliggende artikel zal dit intertekstualiteitsmodel consequent toegepast worden op Brakmans roman en Apollonius' epos. Bovendien zullen we 
aantonen dat deze roman volgens de postmodernistische poëtica bij uitstek een parodie op de mythe is. De vergelijking tussen de bron- en doelversie zal een bijdrage leveren aan de verdieping van intertekstueel onderzoek binnen postmodernistisch proza. Mijn keuze voor juist deze roman wordt gemotiveerd door het feit dat hij tot de noemenswaardige werken behoort van de postmoderne literatuur waarin antieke motieven worden bewerkt en dat hij zich goed leent voor het intertekstuele onderzoek. De gekozen methode leek me geschikt omdat Genettes benadering het meest uitgewerkte model biedt voor intertekstuele duiding van teksten, vooral het onderzoek naar de verhouding tussen hypo- en hyperteksten. In het vervolg zal ik nagaan welke aanpakwijze Brakman toepast en welke overeenkomsten en verschillen zijn vast te stellen tussen de antieke tekst en de postmoderne variant. De roman is bovendien waardevol voor beter begrip van postmodernistische poëtica.

De mythe over de Argonauten kennen we uit verschillende bronnen. De meest bekende is het epos De Argonautica dat rond 250 v.Chr. door de Alexandrijnse dichter Apollonius Rhodius werd geschreven. De Argonautica beschrijft de tocht van Jason en de Argonauten naar Colchis, het ophalen van het Gulden Vlies en hun terugreis naar Iolkos. Het vervolgverhaal over hoe Jason en Medea zich op koning Pelias wreken is in boek 7 van de Metamorfosen (1-8 n.Ch.) van Ovidius terug te vinden. Euripides' tragedie Medea (431 v.Chr.) vertelt over het verblijf van Jason en Medea in Corinthe, waarheen ze vanwege de moord op Pelias verbannen werden, over Jasons ontrouw met Glauke en over Medea's wraak op Jason. ${ }^{1}$ Voor ons onderzoek is het epos De Argonautica relevant omdat het voor Brakman de basis vormde voor het herschrijven van de mythe. Voor een beter begrip zullen we eerst de avonturen van de Argonauten in het kort weergeven en De Argonautica met Brakmans roman vergelijken om zowel overeenkomsten als verschillen vast te stellen.

\section{Vergelijking tussen de versies van Apollonius en Brakman}

Willem Brakman baseerde zich op Apollonius' epos bij het schrijven van zijn eigen versie van de Argonauten-mythe. In zijn in 1992 verschenen roman Een vreemde stam heeft mij geroofd laat Brakman het verhaal spelen aan de Noordzeekust van de Lage Landen. De handeling wordt geplaatst in een fictieve tijd van de

${ }^{1}$ Er zijn wel andere bronnen waarin de Argonautenlegende beschreven of vermeld wordt: Pythische Oden (5e eeuw v.Chr.) geschreven door de Griekse dichter Pindarus, De Bibliotheca (1e eeuw n.Ch.) door Apollodorus van Athene, De Argonautica (1e eeuw n.Ch.) door de Romeinse dichter Gaius Valerius Flaccus, Grieks epos Argonautica Orphica (5e eeuw n.Ch.) door een onbekende auteur. Verslagen over de Argonautentocht vinden we ook in werken van Griekse historici: Strabo, Diodoros van Sicilië en Timaeus van Tauromenium. 
Griekse belegering van de Noordzeekust. De Grieken brengen hun goden mee terwijl de oorspronkelijke bevolking de Grote Moeder aanbidt. De Argonautentocht op de Noordzeekust is geen verzinsel van Brakman. Volgens versies die terug te vinden zijn in Argonautica Orphica en bij Timaeus zeilden de Argonauten via de Noordzeestreken en Gibraltar terug naar Griekenland, terwijl in de versies van Apollonius, Apollodorus en Diodoros van Sicilië de Argonauten langs de Donau passeerden (Graves 1999: 464, 465).

Zowel De Argonautica als Brakmans roman zijn episodisch opgebouwd. Brakman houdt zich in grote lijnen aan het oorspronkelijke verhaal, maar in sommige belangrijke aspecten wijkt zijn roman sterk af van het origineel. Uit de onderstaande vergelijking blijkt dat de chronologische volgorde van De Argonautica bij Brakman doorbroken wordt, sommige episodes worden weggelaten terwijl andere ingevoegd worden.

In het vervolg zullen we iets gedetailleerder ingaan op alle transformaties die het Argonautenverhaal in Brakmans roman heeft ondergaan en daarna zullen we elke wijziging volgens Genetts theorie classificeren.

De Argonautica van Apollonius zet in met het voorbereiden van de Argonauten op de tocht naar Colchis. Brakman begint met de beschrijving van Jasons kindertijd en jeugd. Jasons kindermeid verkoopt hem op de markt in Scheveningen en hij groeit op bij oom Arie en een Kentaur. Jason komt in Zeebrugge in dienst bij de beurtschipper De Kraker, die hem alles over de scheepsvaart leert; als deze Jason slecht begint te behandelen, laat Jason in samenzwering met vrouw Boender, de Puthia van het orakel in Scheveningen, De Kraker vermoorden en neemt hij diens schip over.

In de Argonautica wordt ernaar verwezen dat Jason opdracht van Pelias heeft gekregen om het Gulden Vlies uit Colchis te halen. Als hij de taak volbrengt, mag Jason zijn recht doen gelden op de troon van Iolkos die Pelias twintig jaar geleden aan Jasons vader ontnomen heeft. Bij Brakman krijgt Jason opdracht van een boerin in Ossenisse het vlies uit de Zeustempel te Zeebrugge te stelen, het naar de noordelijke Umbralanden te vervoeren en later naar Zeebrugge weer terug te brengen.

De eerste halte van de Argonauten is het eiland Lemnos waar alleen vrouwen wonen. Ze hebben alle mannen vermoord omdat deze met slavinnen vreemdgingen. Aldaar heeft Jason een relatie aangeknoopt met koningin Hypsipyle. Bij Brakman wordt Walcheren overwegend bewoond door vrouwen, maar er zijn ook mannen aan te treffen. In plaats van Hypsipyle ontmoet Jason Kore. Deze episode wordt uitgebreid doordat de Argonauten terechtkomen in de buik van een monster.

In de Argonautica vermoordt Jason op het eiland der Dolionen per ongeluk koning Cyzikus met wie hij intussen bevriend geraakt was. Bij de voortzetting van de vaart worden de Argonauten door zesarmige reuzen met stenen begooid, maar Heracles overmeestert ze allemaal. Heracles blijft in Mysië zijn schilddrager Hy- 
las zoeken die door nimfen naar het water gelokt werd. Bij Brakman is de episode met Cyzikus helemaal weggelaten. De Argonauten worden echter langs Willemstad bekogeld met stenen door mannen met zwarte petjes en vrouwen met witte petjes, maar Herakles weet ze te overwinnen. In tegenstelling tot de Argonautica blijft Herakles nog een tijd lang op het schip.

In de Argonautica komen de Argonauten in Bythinia bij Bebryken waar koning Amycus regeert die de vreemdelingen tot een vuistgevecht uitdaagt. Hoewel de koning sterker is, wordt hij door bokskampioen Polydeuces verslagen. Bij Brakman bokst Herakles met Grote Pier, een reusachtige man, die verslagen wordt.

In Thrakië komen de Argonauten de blinde koning Phineus tegen die door Apollo gestraft werd met harpijen, half-vrouwen, half-vogels, die zijn voedsel stelen. Bij Brakman ontmoet Jason Fineus in een ziekenhuis in Brielle waar zuster Dillinger en andere verpleegsters (harpijen) zijn eten bevuilen.

Verder slagen de helden in de Argonautica met de hulp van godin Pallas Athena erin om door de Symplegaden, de gevaarlijke rotsen die onophoudelijk tegen elkaar botsen en alles wat ertussendoor komt verpletteren, te passeren. Deze episode komt bij Brakman helemaal niet voor. In plaats daarvan komen de Argonauten naar de Noordelijke Umbralanden waar wilde mensen leven. Hier passeren ze Harlingen, waarin de onderwereld zich bevindt, ontmoeten de zeegod Nereus en zien Atlantis. Herakles blijft pas nu Hulas zoeken.

Op het eiland Aria worden de Argonauten door stymphaliden, vogels met koperen veren, aangevallen. Bij Brakman begooien vogels de Argonauten met uitwerpselen.

In de Argonautica raadplegen Hera, Athene en Aphrodite elkaar om Jason te helpen. Aphrodite stuurt haar zoontje Eros om zijn liefdespijl in Medea's hart te schieten. Brakman voert de godinnen niet ten tonele. In plaats daarvan krijgen de Argonauten van Driesumers, een kannibalistisch volk, zonder het te weten, een dikke jongen te eten.

In de originele mythe eist Jason, in Colchis aangekomen bij Aietes, het Gulden Vlies op, maar krijgt van de koning opdracht met vuurademende stieren de akker met drakentanden te bezaaien. Uit die tanden groeien gewapende mannen die hij moet neerslaan. Brakman plaatst Colchis in Moddergat. Hier wonen de hereboer Aietes en zijn dochter Medea, priesteres van de halfgod Prometheus. Zodra Aietes hem heeft gezien, weet hij dat een troebele droom zal uitkomen. Hij droomde ooit over een jongen die met vuurademende stieren de akker beploegde en de uit slangetanden ontsproten strijders doodsloeg.

In de Argonautica helpt Medea Jason de strijders te bevechten door hem een magische zalf te geven. Samen stelen ze het vlies waarna ze met Jason en zijn kameraden vlucht. Bij Brakman is deze episode tot absurditeit gereduceerd: eerst 
schenkt Jason tot de verbazing van zijn varensgezellen het vlies aan Aietes, daarna steelt hij het samen met Autolukos terug.

In de Argonautica vermoordt Jason Medea's broer Apsyrtos die met zijn leger de vluchtende Argonauten achternazat. Bij Brakman vermoordt Jason niet alleen Adsurpos maar ook diens vader Aietes. Als lezer komen we dit te weten in een terugblik, verteld door Jason na muiterij op het ship. Onduidelijk blijft of Medea hem daarbij heeft geholpen.

In de Argonautica gaan Jason en Medea naar de tovenares Circe om zich te laten reinigen van de afschuwelijke misdaad. Daarna trouwen Jason en Medea uit vrees dat de koning der Phaiaken Alkinoös Medea zou uitleveren aan het leger van Colchis. Deze episodes zijn bij Brakman weggelaten. In plaats daarvan worden de Argonauten aangevallen door de Bacchanten, aangevoerd door Medea, die vloek over de Argonauten uitspreekt. De meeste Argonauten verongelukken na de thuiskomst.

Zowel in de Argonautica als in Brakmans roman stranden de Argonauten en moeten het schip door de woestijn dragen. Terwijl bij Apollonius de zeegod Triton hen de weg naar zee wijst, verschijnt Triton bij Brakman als levensgenieter.

Uiteindelijk komen de helden naar Iolkos terug. Daarmee eindigt het epos van Apollonius. Het einde is bij Brakman iets uitgebreider: Jason keert terug naar vrouw Boender. Het vlies wordt naar de Zeustempel te Zeebrugge gebracht, vanwaar het per expresse naar Moddergat wordt opgestuurd.

\section{Intertekstuele verhoudingen binnen de roman Een vreemde stam heeft mij geroofd}

Om aan te tonen welke veranderingen Brakman in het Argonautenverhaal heeft aangebracht gaan we uit van de intertekstualiteitstheorie van Gérard Genette die hij in zijn studie Palimpsestes. La Littérature au second degré (1982) uitgewerkt heeft. Het overkoepelende begrip in zijn theorie is transtekstualiteit (Genette 1993: 9). Van de verdere onderverdeling die Genette presenteert, zijn voor een analyse van Brakmans roman vooral intertekstualiteit en hypertekstualiteit van belang.

\subsection{Citaten en plagiaat}

Volgens de theorie van Genette worden er tot het ondertype intertekstualiteit drie vormen gerekend: citaat (met aanhalingstekens, met of zonder bronvermelding), plagiaat (een niet aangegeven letterlijke ontlening) en toespeling (Genette 1993: 10). Brakman gebruikt onder andere letterlijke citaten van Nederlandse auteurs. Bij de citaten vermeldt Brakman de bronnen niet, maar hij plaatst ze wel tussen aan- 
halingstekens. Al de geciteerde verzen worden aan Orpheus toegeschreven. In de roman komen we citaten tegen uit Simon Vestdijks gedicht Zelfkant: "Ik houd het meest van halfland'lijkheid" (Brakman 1992: 52), Marsmans De boot van Dionysos: "Dolfijnen om de kiel, in de mast een druivelaar" (Brakman 1992: 77), Slauerhoffs In mijn leven: "In mijn leven, steeds uiteengerukt / Door de vlagen waar 'k aan blootsta..." (Brakman 1992: 65), uit het gedicht Tuin van Hendrik de Vries zijn twee citaten genomen: "Geurloos in 't fluweel azuur,/ Bloeit het onuitblusch'lijk vuur" (Brakman 1992: 86) en "Onder maat'loos groen bedolven,/ Wierookt stervensdroef jasmijn" (Brakman 1992: 111). Plagiaat komt voor in zinnen waarin de overgenomen delen zonder aanhalingstekens binnen de tekst ingevoegd zijn: "gebeeldhouwde sonnetten" (Brakman 1992: 11) uit het gedicht Aan de sonnetten (I) van Jacques Perk en "van erts tot arend" (Brakman 1992: 62), een bekende regel en de titel van het essayboek van Adriaan Roland Holst. Hierop moet opgemerkt worden dat volgens de postmodernistische poëtica het plagiaat geen vergrijp is tegen de goede zeden van de schrijfvakmanschap. De postmoderne kunst is per se een citatenkunst. Ze veronderstelt namelijk de letterlijke overname van reeds bestaande bronnen, waarmee een intellectueel spel ontstaat dat de eruditie van de lezer vereist. Het gaat over het opzettelijke en doelgerichte gebruik van citaten die steentje voor steentje een mozaïek van betekenissen opbouwen.

\subsection{Transformatie}

Voor ons onderzoek is de hypertekstualiteit van belang. Die wordt als volgt onderverdeeld (Genette 1993: 44):

\begin{tabular}{|c|c|c|c|}
\hline verhouding & speels & satirisch & ernst \\
\hline transformatie & parodie & travestie & transpositie \\
\hline imitatie & pastiche & persiflage & reproductie \\
\hline
\end{tabular}

Een wezenlijk verschil tussen transformatie en imitatie is dat bij de transformatie een verhaal inhoudelijk verandert terwijl de imitatie nabootsing van de stijl van een auteur betekent.

\subsubsection{Parodie}

Karakteristiek voor een parodie is volgens Genette de verandering van betekenis door minimale transformatie in een tekst (Genette 1993: 40). Daarbij houdt de parodie onvermijdelijk ironische connotaties in (Genette 1993: 39). Als we de 
definitie van de parodie als "vervanging van een heroïsche handeling door een triviale" (Genette 1993: 39) aanvaarden, dan is de roman van Brakman een parodie bij uitstek. Brakman herschrijft de mythe op een speelse en ironische manier. De Argonauten lijden aan angst, ze zijn helemaal niet heldhaftig. Tijdens gevechten houdt Jason zich op een veilige plaats en draagt oordopjes. Toen Herakles met priesteres Omfale leefde, ontdekte hij "dat hij altijd een vrouw had willen zijn. Hij trok dan ook vrouwenkleren aan" (Brakman 1992: 148). De parodie komt ook tot uiting in het feit dat Jason zijn metgezellen niet bij naam kent. Bovendien is het Gulden Vlies een vervalsing wat de hele onderneming zinloos maakt. Verder vinden we bij Brakman niets van de hoogdravendheid van de klassieke mythes. In de klassieke epen worden er aan de helden goddelijke krachten toegeschreven en in de regel zijn ze van hoge afkomst. Brakmans Jason is daarentegen een gewoon mens die, zoals later blijkt, niet voorbestemd is om een held te zijn.

Volgens theoretici als Meletinsky, Frye en Hutcheon is de bewerking van mythes in de twintigste eeuw altijd ironisch en als parodie bedoeld. De mythische overleveringen probeerden antwoorden te vinden op de meest complexe vragen over de oorsprong en de zin van het menselijk bestaan. De ontwikkeling van de wetenschap heeft echter de geestelijke behoeftes van de mens niet kunnen bevredigen. De geestelijke crisis die de wetenschappelijke uitvindingen steeds meer verergerden vindt haar uitdrukking in ironische literatuur. Voor Linda Hutcheon is de postmoderne kunst over het algemeen van nature een parodie (Hutcheon 1996: 9). Ze defineert de parodie "as imitation with critical ironic distance (...) Irony participates in parodic discourse as strategy" (Hutcheon 1985: 31-37). Ook Eleazar Meletinsky ziet ironie en zelfironie als stijlmiddelen waardoor de grote afstand tussen de moderne mens en de oermythische tijd wordt overbrugd (Meletinsky 1983: 303). Volgens hem komt het mythische als tegenwicht tot het moderne voor. Hij merkt op dat bij vele auteurs in de twintigste eeuw het gebruik van mythes nauw verbonden is met de teleurstelling over de maatschappelijke orde, met angst voor historische omwentelingen, alsook met twijfel aan de mogelijkheid van vooruitgang in het menselijk leven en -bewustzijn (Meletinsky 1983: 304).

Volgens Northrop Frye begint het inbrengen van ironie als stijlfiguur al in het realisme en manifesteert die zich steeds meer in de mythe (Frye 1973: 42). De verhalende literatuur kent volgens Frye een cyclische ontwikkeling die uit verschillende fasen bestaat (myth, romance, high mimetic, low mimetic, irony). De mythes duiken weer op in de ironische fase, maar in tegenstelling tot de oorspronkelijke mythes met goden en krachtige helden als hoofdpersonages hebben wij in de ironische fase te maken met zwakke en inferieure helden (Frye 1973: 33-34). Zo wordt bij Brakman Jason door één van zijn reisgenoten als volgt beschreven: "Jasons grootvader was een Kentaur, een onzeker wezen en daarom is hij zoals 
hij is geworden, een wankele stuur die het roer graag uit handen geeft" (Brakman 1992: 161).

Bijgevolg dient de mythe in de twintigste eeuw als uiting van kritiek en herinterpretatie met een parodistisch karakter. Brakman uit op deze manier impliciet kritiek op de op de ratio gebaseerde beschaving. In deze roman manifesteert zich het ironische besef dat de wereld van de ratio niet toereikend is om het leven als geheel te vatten. Dat zien we onder andere in de scène waar de motor van het schip kapot gaat zodat de Argonauten moeten roeien. Techniek biedt dus geen houvast. Het getuigt van de onmogelijkheid om de natuur volledig te beheersen. Als de Grieken hun goden meebrengen "werd er als hoogste wijsheid verkondigd dat de akker met verstand diende [te worden] geploegd, geëgd" (Brakman 1992: 12). De heerschappij van Zeus wordt als iets opgelegds ervaren en dientengevolge in tegenstrijd met de ware menselijke natuur. Jason blijft de hele tijd trouw aan de Grote Moeder, die de oerkrachten van de natuur symboliseert, hoewel hij in opdracht van de patriarchale oppergod Zeus zijn missie uitvoert: "Ik ben de veelnamige Godin meer dan toegedaan want zij is de hoedster van de zachte dingen, voor Zeus had ik eerder vrees en ontzag" (Brakman 1992: 35). "In naam van de Moeder" (Brakman 1992: 31) steelt hij het vlies, het attribuut van de mannelijke god, dat als vervalsing ontmaskerd wordt, wat de hele missie belachelijk maakt. Pas aan het einde beseft hij dat hij de mannelijke goden niet mag vergeten en wijdt hij het schip aan Poseidon, aan wie hij ook één van de kameraden offert.

\subsubsection{Transpositie}

Met behulp van de theorie van Genette kunnen we vaststellen welke transpositionele procédés een auteur ter beschikking staan om een verhaal om te vormen. De transpositie kan formeel en thematisch zijn (Genette 1993: 288).

Eén van de formele transposities is translatie wat de verandering van de modus van een tekst met zich meebrengt (Genette 1993: 289). Brakman past het procédé van prosificatie ${ }^{2}$ toe: hij maakt proza van de oorspronkelijk in verzen geschreven tekst. Verder bedient hij zich van enkele technieken van narrativisatie, ${ }^{3}$ zoals focalisatie (we hebben hier een ik-verteller: Jason), analepsis (terugblik) en meestal indirekte rede. Tot de formele transpositie behoort ook transstilisering. Genette maakt verschil tussen stilisering als de hypertekst in een hogere stijl is geschreven en ontstilisering als deze in een lagere stijl wordt geschreven (Genette 1993: 311), wat het geval is bij Brakman. Formeel zijn ook kwantitatieve transformaties van een hypertext. Twee van deze procédés worden door Brakman ingezet: reductie (weglating) en extensie (uitbreiding) (Genette 1993: 313-314).

\footnotetext{
${ }^{2}$ Over de prosificatie Genette 1993: 297.

3 Over de narrativisatie Genette 1993: 388.
} 
Brakman laat in zijn roman sommige zeer belangrijke scènes uit het mythische verhaal weg. Zo wordt Pelias in de roman helemaal niet vermeld. Symplegaden, één van de belangrijkste episodes in de Argonauten-mythe is helemaal weggelaten. Tovenares Circe, die Jason en Medea van de zonde reinigt, komt niet opdagen in de roman van Brakman. De toevlucht tot Alkinoös en de geheime bruiloft van Jason en Medea vinden niet plaats in deze roman. Eros, die zijn pijl in Medea's hart schiet, komt niet voor. Een verklaring voor deze reducties kunnen we vinden in het feit dat Brakman het verhaal rationeler heeft gemaakt. De Olympische goden spelen in De Argonautica een actieve rol. Met de hulp van Pallas Athena passeren de helden de Symplegaden en Medea wordt verliefd op Jason dankzij Eros. Bij Brakman is hun ingrijpen in het menselijk doen en laten helemaal geschrapt. Daar we bij Brakman niet weten of Medea en Jason een relatie hadden, heeft Eros geen functie meer en omdat Brakman het sprookjesachtige vermijdt is ook de episode met de botsende rotsen alsook de toverkrachten van Circe logischerwijs niet ingebracht.

In andere gevallen wordt het originele verhaal juist uitgebreid. Op Lemnos waar in de mythe alleen vrouwen wonen, laat Brakman ook mannen optreden. Zij vormen de bemanning van oorlogsschepen, waaronder zich admiraal Bloys van Treslong ${ }^{4}$ bevindt. Het optreden van admiraal Treslong wijst erop dat de tijdlaag in deze roman onbepaald is. Dit is kenmerkend voor mythologische romans van de twintigste eeuw (Meletinsky 1983: 302). Brakman verweeft niet alleen het Grieks archaïsche met het hedendaagse maar ook met de Tachtigjarige oorlog om de tijdloosheid van zijn verhaal te benadrukken. Een andere uitbreiding zijn de episodes waarin De Kraker, Orpheus en de dikke jongen uit Driesum in stukken worden gesneden. Volgens de mythe wordt Orpheus' lichaam inderdaad door Maenaden uiteengescheurd (Graves 1999: 92). Het verscheuren van een lichaam verwijst naar een ritueel dat J.G. Frazer in zijn studie The Golden Bough nauwkeurig heeft beschreven: Het betreft daar een koningsmoord; de ziel en de kracht van de koning worden hiermee op zijn jonge erfgenaam overgedragen ter bevordering van vruchtbaarheid en voorspoed (Frazer 2003: 267-268). De moord op De Kraker betekent de initiatierite voor Jason die diens schip overneemt en zich pas nu als aanvoerder kan profileren. De Kraker heeft hem ingewijd in het zeemanschap en kan zodoende als Jasons geestelijke vader beschouwd worden.

Ook continuatie (voortzetting) ziet Genette als vorm van uitbreiding (Genette 1993: 222); deze kan analeptisch, proleptisch en paraliptisch (Genette 1993: 241) zijn. Alle drie de procédés komen we in de roman tegen. Analepsis vinden we aan het begin van het boek wanneer Jasons kindertijd en jeugd ingevoegd worden. Aan het einde van de roman treffen we prolepsis aan: na de vloek van Medea ko-

${ }^{4}$ Willem Bloys van Treslong (1529-1594), één van de aanvoerders van de watergeuzen tijdens de Tachtigjarige oorlog. 
men we te weten hoe het gesteld was met het leven van de Argonauten. Bijna allen komen om het leven; Orpheus wordt bijvoorbeeld verscheurd door vrouwen. Alleen Jason meent de vloek te zijn ontkomen. Tot paralipsis (nevenepisode die in het origineel helemaal niet voorkomt) kunnen we de episodes met De Kraker, vrouw Boender en de Bacchanten rekenen.

Contaminatie in de zin van het vermengen van twee hypoteksten is eveneens een soort uitbreiding. (Genette 1993: 358). In deze roman vinden we volgende combinaties met andere mythen: Jason wordt verwond en loopt een tijdje mank, wat een directe verwijzing naar de Oedipus-mythe is. Ook de moord op De Kraker die Jason bewerkstelligt kan in de zin van Oedipus' vadermoord geïnterpreteerd worden. Aan het einde van de roman keert Jason terug naar vrouw Boender wat de twee met Odysseus en Penelope identificeert. Jasons terugkeer naar vrouw Boender kan geïnterpreteerd worden als terugkeer naar een vorm van huiselijke geborgenheid waarnaar ook de slotzin van de roman verwijst: "Men zegt dat wie reist vrijer, machtiger, ja gelukkiger wil zijn dan hijzelf, in deze zin reisde ik mijn verleden tegemoet om mij ten slotte als de thuiskomende te hervinden" (Brakman 1992: 210). De Argonauten komen in Walcheren terecht in de buik van een monster. Dit is een verwijzing naar het Bijbelse verhaal over Jona die door een grote vis opgeslokt wordt. Brakman combineert de episode in Lemnos met de Bijbelse mythe en daarmee verbindt hij verschillende mythologische tradities. Jason ontmoet hier Kore. De buik van het monster wordt vergeleken met de onderwereld waarin Kore (Persephone) de ene helft van het jaar in Hades verblijft terwijl ze de andere helft met haar moeder Demeter op aarde doorbrengt. Een andere referentie naar de Bijbel is het verhaal over Jozef en zijn broers. Die vinden we in de scène waarin Jason als droomuitlegger aan Aietes voorgesteld wordt. Verder steelt Jason het Gulden Vlies uit een labyrint wat een toespeling is op de mythe over Theseus en Ariadne. Nereus, de zeegod, verschijnt bij Brakman, maar in Apollonius' epos wordt hij niet genoemd. De Argonauten zien een eiland dat opduikt en steeds verder onder water verdwijnt naargelang men het nadert. Dit is een verwijzing naar de Atlantis-mythe.

De tweede soort transpositie is thematische (semantische) transpositie die Genette verder onderverdeelt in diegetische, pragmatische en zuiver semantische (psychologische) transpositie (Genette 1993: 404).

Diegetische transpositie die Genette ook transdiegetisatie noemt is de verandering van de diegese, dit wil zeggen van de plaats en tijd waarin de personages leven. Diegese bevat het geografisch-historische kader (Genette 1993: 406). Wat de personages betreft, kunnen ze hun naam behouden en dan is er sprake van homodiegetische transpositie en als ze hun namen veranderen spreekt men van heterodiegetische transpositie (Genette 1993: 407-408). In de roman van Brakman hebben we homodiegetische transpositie hoewel de namen van sommige personages orthografisch licht gewijzigd zijn, bijv. Apsyrtos - Adsurpos. Elke diegetische 
transpositie bedient zich volgens Genette van approximatie (benadering) (Genette 1993: 415), met andere woorden: het publiek moet nader vertrouwd gemaakt worden met het verhaal. Zo speelt het verhaal zich af in de Lage Landen, het orakel bevindt zich in Scheveningen in plaats van Delfi, de onderwereld is in Harlingen en Colchis in Moddergat.

Wat de tijd betreft, is het de vraag of de handeling van de roman in de twintigste eeuw plaatsvindt. Aan de ene kant zijn er cafés, hotels, maar aan de andere kant vechten de Argonauten met zwaarden, speren en bijlen. Meletinsky wijst erop dat de relativistische opvatting van de tijd karakteristiek is voor de moderne roman. Hij beroept zich op het essay van Joseph Frank Spatial form in the modern literature waarin wordt geponeerd dat de mythologische tijd in de moderne roman de objectieve historische tijd verdringt, aangezien handelingen en gebeurtenissen in een bepaalde tijd als belichamingen van eeuwige prototypes getoond worden. De wereldse tijd van de geschiedenis wordt tot tijdloze wereld van de mythe wat zich ook in de ruimte uitdrukt (Meletinsky 1983: 302). Mircea Eliade maakt onderscheid tussen de heilige tijd en de profane tijd. De heilige tijd die verandert noch afloopt is onbeperkt herhaalbaar en omkeerbaar. Ze wordt periodiek opnieuw actueel gemaakt als een soort mythische eeuwige aanwezigheid door rituelen die voortkomen uit het verlangen van de mens "zo dicht mogelijk bij zijn goden te leven" (Eliade 2006: 62).

Pragmatische transpositie, ook transpragmatisatie genoemd, omvat modificatie van handeling of van object, alsook correctie van de hypotekst (Genette 1993: 425). Modificatie van handeling komt duidelijk naar voren in het feit dat Jason de hele tijd het vlies in zijn rugzak heeft, het aan Aietes schenkt en later terugsteelt. Ook Jasons relatie met Medea is in de roman van Brakman helemaal niet duideliijk. We weten niet of Medea op Jason verliefd was en hem geholpen heeft het vlies te stelen. Er zijn wel verwijzingen in de roman die erop duiden dat Medea de minnares van Jason was. Modificatie van object zien we bijvoorbeeld in de episode met vogels met koperen veren, bij Brakman zijn dat uitwerpselen die ze op de Argonauten gooien. Orpheus' lied lokt sirenen en bij Brakman robben en dolfijnen.

Bij zuiver semantische transpositie gaat het volgens Genette om psychologische transpositie. Bij de diegetische transpositie worden er de vragen waar en wanneer gesteld, bij de pragmatische wat en hoe en bij de psychologische waarom. Belangrijk is daarbij de motivatie van de personages alsook hun rol, dat wil zeggen hun valorisatie (Genette 1993: 440).

In een hypertext komt het vaak tot motiefwisseling die positief, negatief en substituerend kan zijn. Genette spreekt dan van motivatie, demotivatie en transmotivatie (Genette 1993: 439-440). Bij Brakman vinden we bij sommige personages (toegevoegde) motivatie. Adsurpos wil de moord op zijn vader Aietes wreken. In de originele mythe wordt Aietes niet vermoord, hij stuurt zijn zoon Apsyrtos 
achter Medea en Jason aan. Adsurpos heeft hier een toegevoegd motief om Jason te vervolgen, maar uiteindelijk verraadt Brakman het originele verhaal niet omdat Adsurpos door de hand van Jason gedood wordt.

Als een motief weggelaten is, dan is er sprake van demotivatie (Genette 1993: 444). Jason moet zijn troon heroveren in de mythe, maar bij Brakman heeft hij dit hogere doel niet op het oog, in het bijzonder omdat het vlies een vervalsing blijkt te zijn.

In de mythe eist Jason de troon op en krijgt een opdracht van Pelias. Bij Brakman krijgt hij de opdracht van een boerin, dus hij heeft een ander motief om het vlies te halen. Om met Genette te spreken gaat het in dit geval over transmotivatie (Genette 1993: 448).

Wat de rol van de personages betreft, kunnen sommige personages een belangrijkere of een mindere rol toegewezen krijgen in vergelijking met een hypotext. Dan spreekt Genette over de valorisatie van de personages die weer positief kan zijn: valorisatie (opwaardering), negatief: devalorisatie (afwaardering) en complex: transvalorisatie (substitutie, rolwisseling) (Genette 1993: 464).

De personages die opgewaardeerd worden bij Brakman zijn: Autolukos die Jason helpt bij het stelen van het vlies, Herakles die langer verblijft bij de Argonauten, Jason die dromen kan uitleggen. Ook goden kunnen een belangrijkere rol krijgen, bijvoorbeeld heeft Prometheus zijn eigen tempel. Andere personages zijn afgewaardeerd zoals Medea, hoewel we alleen impliciet kunnen vaststellen dat zij een mindere waarde krijgt, omdat we er tot het einde van de roman niet zeker van zijn welke rol ze had. Aietes is geen koning maar een hereboer. Koning van Bebryken Amycus wordt bij Brakman de aan Poseidon geofferde jongen. En in plaats van koning Amycus vecht een zekere Grote Pier met Herakles. Mopsos begrijpt de taal van vogels niet echt. Jasons gevecht met reuzen (die uit de drakentanden geboren zijn) wordt gedevalueerd tot een droom van Aietes. Daarenboven zijn de helden bang, soms wenen ze alsnog. Transvalorisatie of rolwisseling treffen we aan in volgende gevallen: op het vrouweneiland ontmoet Jason een meisje Kore genaamd in plaats van koningin Hypsipyle zoals het in de oorspronkelijke mythe is. Bij Apollonius vechten Polydeuces en koning der Bebryken Amycus, maar bij Brakman raken Herakles en Grote Pier in een vuistgevecht verwikkeld. Jason vermoordt Aietes in plaats van koning Cyzikus. Autolukos (in plaats van Medea) helpt Jason het vlies te stelen. Er is in Brakmans versie nergens sprake van koningen. Ze worden vervangen door andere personages (Hypsipyle, Amycus) of helemaal weggelaten (Cyzikus) of in functie gedegradeerd (Aietes is een hereboer en Fineus is slechts een blinde). In grote mythische verhalen spelen naast goden en helden ook koningen een aanzienlijke rol. Daartegenover worden ze in een parodie, wat deze roman inderdaad is, van hun bovennatuurlijke of koninklijke waardigheid ontdaan. 


\subsection{Postmodernistische scepsis}

Brakman gaat een dialoog aan met teksten, tradities en mythen, maar hij ironiseert, relativeert en ondermijnt ze radicaal. In deze roman zien we het vooral in het feit dat Jason en de Argonauten geen echte helden zijn en dat het gulden vlies een imitatie is. Een vreemde stam heeft mij geroofd is een roman die typisch postmodernistisch van aard is. Zoals in andere romans van Brakman wordt hier ook het probleem van de verhouding tussen verbeelding en werkelijkheid geproblematiseerd. De romanwereld is geen afspiegeling van de werkelijkheid. De bedoeling is de lezer duidelijk te maken dat de romanwerkelijkheid geen echte werkelijkheid is, maar een fictie. De traditionele structuurelementen van de roman zoals personage, tijd, ruimte en vertelwijze worden ondergraven. De personages zijn psychologisch niet te doorgronden, ze zijn niet voorspelbaar en Jason is als verteller niet te vertrouwen. De tijd wordt ook als fictie ontmaskerd, de tijdlagen lopen door elkaar heen. De ruimte buiten en de ruimte binnen (in het hoofd van de verteller) vloeien in elkaar over. Het blijkt uiteindelijk dat alles in de tekst voortkomt uit de verbeelding van de verteller. Op de achterflap van het boek staat vermeld dat het eigenlijk over "een reis door het eigen hoofd" gaat. De romanwerkelijkheid is een constructie van beelden, fantasieën, voorstellingen en dromen. Dit alles leidt ertoe dat de logica ontwricht wordt, zodat het soms moeilijk is de betekenis van deze roman te ontsluiten. Bovendien bestaat de tekst uit een overvloed aan beelden. Brakman is "geen logicus die zoekt naar de chronologische ontwikkeling van een verhaaltje, maar een puzzelaar die beelden in elkaar past tot ze een rijk en meerduidig mozaïek vormen" (Vervaeck 1989). Zo is het ook in deze roman, waarin de verhalen steeds aansluiten bij andere verhalen die buiten het kader van het originele epos vallen.

\subsection{Onbetrouwbare verteller}

In de roman hebben we te maken met een onbetrouwbare verteller. De vragen die open blijven zijn: Helpt Medea Jason bij het stelen van het vlies? Waren ze samen toen Jason Adsurpos vermoordde? Deze episodes worden in de terugblik verteld en alles wat we te weten komen is afkomstig van Jasons verhaal. Maar kunnen we hem vertrouwen?

Er zijn aanduidingen in de roman op grond waarvan we kunnen concluderen dat Jason en Medea toch een relatie hadden, hoewel het niet duidelijk is van welke aard want Jason vertelt in de terugblik: “...en de lange en boze tijden braken aan dat Medea en ik onafscheidelijk waren, maar wat is onafscheidelijk bij een zo genadeloze achtervolgster" (Brakman 1992: 194). Eerst kunnen we veronderstellen dat ze verliefd geraakt was, niet door Eros' liefdespijl maar door een ster waarvan ze tegen haar vader Aietes in zijn droom vertelde: "Een ster, zei ze aldaar, had 
zich van het firmament losgemaakt en was in een wijde boog, maar met griezelige precisie, als een kosmische gemme in haar schoot verzonken, wat haar op slag doodzenuwachtig had gemaakt" (Brakman 1992: 163). Jason als droomuitlegger bevestigt dat hij zelf die ster was: "Daarom mag ik zeggen, o Aietes, dat uw droom een profetische was en ik degene die daar langs de nachtelijke hemel ging van uw zo schone dochter" (Brakman 1992: 168). Verder lukt het Jason en Autolukos hoogstwaarschijnlijk door toedoen van Medea het vlies te roven. Als ze de slang naderen zegt Autolukos: "Ik denk dat hij net is gevoed met een paar hanen die besprenkeld waren met een slaapverwekkend sap" (Brakman 1992: 178). Jason en Autolukos voeren deze opdracht in een labyrint uit, waaruit we kunnen opmaken dat Medea Jason geholpen heeft zoals Ariadne Theseus bijstond.

Net voordat Jason Medea's broer vermoordde, trof deze hem aan "in de innige omstrengeling met zijn zuster" (Brakman 1992: 191). Later riep Medea "dat er in waarheid geen ongelukkiger vrouw bestond dan zij: hatend wat zij het meest begeerde en begerend wat zij het meest haatte. De ruïne was zij van haar geslacht en een verraadster van de lankmoedige halfgod uit Moddergat" (Brakman 1992: 193). Dit alles wordt in een flashback door Jason verteld en daarbij benadrukt hij dat dit op geruchten berustte: "Dat is ook de pest met verhalen in de terugblik, ze maken slim gebruik van herinneringen, voorstellingen, dromen, fantasieën en tot de ergste geruchtenverspreiders behoort men zelf" (Brakman 1992: 193). Aan het einde van de roman weet Jason niet meer wie Medea was en vraagt zich af: "Was Medea niet anders dan de woede en de schaduw van de Grote Moeder" (Brakman 1992: 206).

\section{Conclusie}

Brakmans Argonautica is een apocriefe versie van het verhaal over de mythische zeetocht. De parodiëring draagt ertoe bij dat het tragische van het mythische verhaal afgenomen is en in het absurde getrokken wordt. Deze roman is geen pure bewerking van een gekozen mythe, hij is uit tal van ingewikkelde details opgebouwd die allemaal een diepere betekenis hebben. Brakman toont grote eruditie door verschillende verhaallijnen in te lassen en ze vakkundig te combineren. "Het boek is in zijn geheel een literaire reminiscentie" (Snijder 1993) aangezien elk verhaal een ander verhaal oproept wat uiteindelijk resulteert in een compilatie van allerlei mythes die tot een eenheid samengevoegd worden. Door uiteenlopende versies is de Argonautenlegende met de tijd uitgedijd en dat is precies wat ook in deze roman het geval is omdat Brakman ons laat zien hoe mythes uit verhalen ontstaan. Brakmans literair en intellectueel spel met bronnen is helemaal in de trant van de postmodernistische poëtica. In de hierboven besproken roman vloeien de teksten voort uit andere teksten totdat de grenzen tussen fictie en werkelijkheid vervagen. 


\section{Bibliografie}

Apolonije sa Rodosa (2007): Ep o Argonautima. Podgorica: Unireks.

Brakman, Willem (1992): Een vreemde stam heeft mij geroofd. Amsterdam: Querido.

Eliade, Mircea (2006): Het heilige en het dagelijkse bestaan. Amsterdam: Uitgeverij Abraxas.

Frazer, James George (2003): Zlatna grana. Beograd: Ivanišević.

Frye, Northrop (1973): Anatomy of Critisism: Four Essays. Princeton: Princeton University Press.

Genette, Gérard (1993): Palimpseste. Die Literatur auf zweiter Stufe. Frankfurt am Main: Suhrkamp.

Gerbrandy, Piet: "Jason in een labyrint van mythen". Wbrackman.nl, laatst geraadpleegd op 10.09.2017 $<$ http://www.eco.rug.nl/ brakman/brakman/Gerbrandy.html $>$.

Graves, Robert (1999): Grčki mitovi. Beograd: Familet.

Hutcheon, Linda (1985): A Theory of Parody. Urbana/Chicago: University of Illionois Press.

Hutcheon, Linda (1996): Poetika postmodernizma. Novi Sad: Svetovi.

Meletinsky, Eleazar Moiseevič (1983): Poetika mita. Beograd: Nolit.

Mourits, Bertram (1993): "Visnimfen met ronde sterke onderarmen". Vooys 11, 111-114, laatst geraadpleegd op 15.04.2018<http://www.dbnl.org/tekst/_voo013199301_01/_voo013199301_01_0029. php>.

Snijder, J.H. (1993): “De Argonauten landen in Harlingen”. Vestdijkkroniek 1993, 42-48, laatst geraadpleegd op 15.04.2018<http://www.dbnl.org/tekst/_ves001199301_01/_ves001199301_01_0010. php>.

Van Boven, Erica, \& Mary Kemperink (2006): Literatuur van de moderne tijd. Nederlandse en Vlaamse letterkunde in de 19e en 20e eeuw. Bussum: Coutinho.

Vervaeck, Bart (1989): "Willem Brakman verklaard? Ernst van Alphen, 'Bij wijze van lezen. Verleiding en verzet van Willem Brakmans lezer'. Muiderberg, Coutinho, 1988". Dietsche Warande en Belfort 134, 235-237, laatst geraadpleegd op 15.10.2018<https://www.dbnl.org/ tekst/_die004198901_01/_die004198901_01_0053.php>. 